【カテゴリーII】

\title{
強風下における機械的固定工法による防水層の挙動の風洞実験による観察 BEHAVIOR OF MECHANICALLY ANCHORED WATERPROOFING MEMBRANE
EXPOSED TO HIGH WIND SPEED OF WIND TUNNEL
}

\author{
市川裕 一*, バルトコミハエル**, 加藤 信 男*, 宮 内博 之*** \\ 佐々木 孝基*, 田中享二**** \\ Hirokazu ICHIKAWA, Michal BARTKO, Nobuo KATOU, \\ Hiroyuki MIYAUCHI, Takanori SASAKI and Kyoji TANAKA
}

\begin{abstract}
A waterproofing membrane is partially fixed to a substrate by fasteners in mechanically anchored systems. For designing a safer anchored waterproofing system against typhoons, it is needed to make clear the behavior of it under strong wind. Two kinds of full size specimens with a parapet and without one were exposed to high wind speed of a wind tunnel. The behavior of the system was investigated from the three aspects such as wind forces to a membrane, deformation of a membrane and tensile forces of fasteners induced by high wind. Strong wind force was observed in the area close to the windward edge for the roof without a parapet and about $1 \mathrm{~m}$ on the leeward from a parapet for the roof with a parapet. The membrane was lifted up by wind to about $60 \mathrm{~mm}$ in maximum height and was extended to about $0.6 \%$ in maximum elongation and it oscillated about $5-20 \mathrm{~Hz}$ in periodic time. The tensile force of more than $160 \mathrm{~N}$ was observed in some fasteners, depending on the location in the roof.
\end{abstract}

Keywords: Mechanically anchored waterproofing system, Wind resistance, Wind tunnel test, Fastener, Parapet 防水層機械固定工法、耐風性、風洞試験、固定金物、パラペット

\section{1.はじめに}

従来の防水層は原則として下地に全面的に密着させているため、 下地のひび割れや、ムーブメント、水分等による影響を受け不具合 が生じることがあった。その解決法の一つとして、防水層をファス ナ一類で点状に機械的に固定させる工法が開発され、乾式工法によ る施工速度の早さ、ALC 板や金属板などの不安定な下地へも施工可 能なこと、既存防水層を撤去することなくその上に新規防水層を施 エできるという補修作業利便性などにより、近年急速にその利用が 拡大している。

しかし、機械的固定工法では一定間隔に設置されたファスナー等 の局部的な支持点だけで、強風に耐えなければならない。現在、建 築基準法などに基づき屋根面での風圧力を求め、充分安全となるよ うにファスナ一等の種類や数等が決定されているが、まだ経験の浅 い工法のため、す心゙ての技術的課題が解決されているとは云い難い 状況にある。

このような状況の中、2004 年秋に台風 18 号、22 号と、最大瞬間 風速 $50 \mathrm{~m} / \mathrm{s}$ を越える暴風雨がわが国を連続して襲来し、強風のため に防水層も被害を受けた。その中に機械的固定工法による防水層も 数多く含まれており（写真 1 ）、ファスナーの抜けや破損以外にも、 機械的固定部分からの防水層の引き裂きや、固定のためのディスク
からの防水層剥離等、防水層側にも原因のある損傷も被害事例とし て多く見られた。

これらは、強風時の風圧力に対して安全なファスナーの数を計算 により求め、それに従って施工寸れば良いといった単純なプロセス だけでは、安全な防水層を作りあげるためには不十分であり、ファ スナーおよび防水層を全体としてとらえた機械的固定工法による防 水システムとしての耐風性の評価、それを踏まえての設計、施工が 必要であることを示唆するものであった。

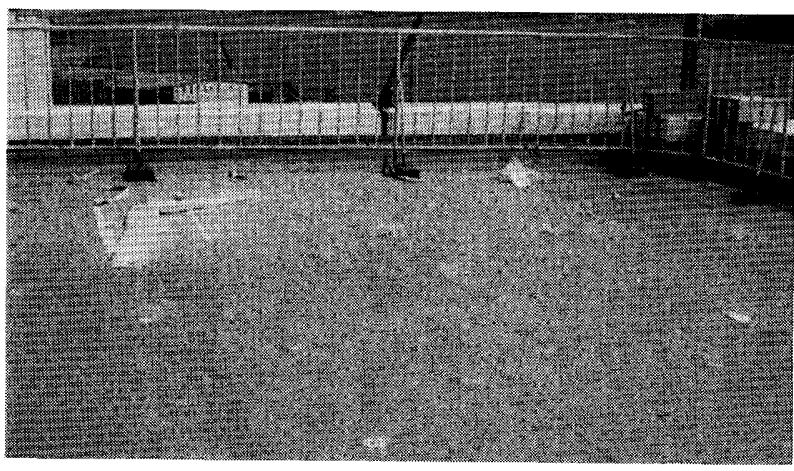

写真1 台風によって防水シートが吸い上げられ ファスナー周辺部が破損した例

\footnotetext{
* 東急建設侏技術本部

** 東京工業大学 大学院生・理修

*** 東京工業大学建築物理研究センター 助手・博士 (工学)

***** 東京工業大学建築物理研究センター 教授・ 工博
}

Engineering Div., Tokyu Construction Co., Ltd.

Graduate Student, Tokyo Institute of Technology, M. Sc.

Res. Assoc., Structural Engineering Research Center, Tokyo Institute of Technology, Dr. Eng.

Prof., Structural Engineering Research Center, Tokyo Institute of Technology, Dr. Eng. 
既往の防水層の耐風性評価研究のほとんどは、防水層の上に箱を かぶせ、内部を陰圧にすることにより模擬的に風による防水層吸い 上げ状態を再現し、それにより評価をしょうとする吸引箱方式によ るものであり、その研究例は多(1-4)。この方式で大まかな防水層 の耐風性能の評価はできるが、赛際の風による防水層の動的挙動を 基とした評価はできず、現実に即した検討のためには、風の流れて いる状態での防水層の挙動の観測が必要である。

実断面をもつ防水層試験体を用いての風洞による研究は、 Baskaran 等 ${ }^{5-7)}$ によって、防水層面に作用する風荷重の大きさ、変 動、周期、分布など外力としての風は明らかにされたが、防水層の 変形やファスナーに作用する力など防水システム全体としての挙動 は不明である。

本研究の最終目標は、風に対して安全な防水層システム設計法の 構築にあるが、本報では第一段階として、実断面をもつ試験体での 機械的固定工法による防水システムの強風時の挙動、特にここでは、 強風時に防水層の受ける風荷重、防水層の変形やひずみ、ファスナ 一に生じる力を風洞試験により明らかにしようとするものである。

\section{2. 実大試験体による風洞実験}

\section{1 試験体}

(1) 概 要

試験体は、図 1 に示寸陸屋根建築物を想定した幅 $2,380 \mathrm{~mm}$ 、長さ $5,500 \mathrm{~mm}$ 、高さ $500 \mathrm{~mm}$ の屋根面に実防水層を施工したものを用いた。

機械的固定工法では、図 2 に示寸ように下地にファスナーで固定 したディスクを防水層と接着し、一体化させる方法が一般的である が、本研究では防水層の着脱を可能とするため接着せずに、防水層 をファスナーの代わりに 32 組（ファスナ一間隔 $600 \mathrm{~mm}$ ：ただし、 風上端のみ風方向間隔 $500 \mathrm{~mm}$ )のボルトとナットで下地に固定した。

また、パラペットの有無による防水層の影響を検討するため、高

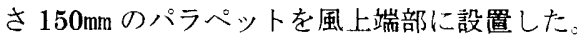

なお、実際の防水層下地は、本工法のような露出防水では水はけ をよくするため1/20１/50の勾配が設けられているが、本実験では 便宜上水平とした。

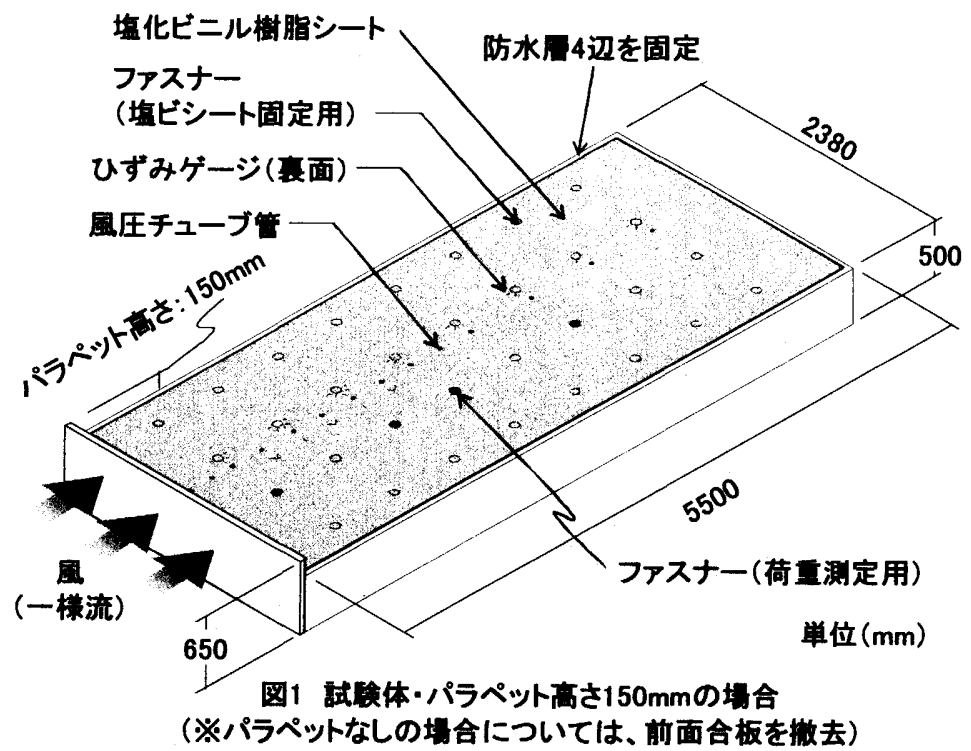

（2）使用材料

下地には厚さ $100 \mathrm{~mm}$ の ALC 板を用い、防水層には図 3 の特性を示 す厚さ $1.5 \mathrm{~mm}$ の塩化ビニル樹脂シート複合タイプを使用した。ファ スナーにはM12 のボルトおよびナットを用い、ディスクは外径 $75 \mathrm{~mm}$ $\phi$ 、板厚 $1.7 \mathrm{~mm}$ の円盤状の金物の中心に M12 のボルトを貫通させる

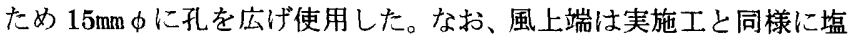
ビ被覆した鋼板を下地に固定し、そこに防水層を熱溶着させている。 （3）下地の通気条件

防水下地である ALC 板の間は、実施工では短辺方向は突きつけで あるが、長辺方向の隙間にはモルタルが充填されている。本試験体 では ALC 板間の隙間、および試験体周辺の防水層固定用の鋼材と ALC 板との隙間にウレタン系シーリング材を充填し、粘着テープを 張った。また ALC 板の固定は、実施工と同様にALC 板表面に座堀 り穴を施し、固定ボルト頭部を板表面より下げ専用補修材で埋めた。 試験体と風洞内の壁面・床面との隙間、パラペット用パネルの接合 部についてもバックアップ材、粘着テープを用い隙間を塞いでいる。 下地の通気条件（下地となる ALC 板を貫通する隙間）となる、測 定のため下地を貫通させた部分を表 1 に示す

表 1 下地の通気条件

\begin{tabular}{|c|c|c|c|}
\hline \multicolumn{2}{|c|}{ 下地貫通材 } & $\begin{array}{l}\text { 孔 径 } \\
(\mathrm{mm})\end{array}$ & $\begin{array}{l}\text { 数 量 } \\
\text { (簓所) }\end{array}$ \\
\hline $\begin{array}{c}\text { ファスナー用ボルト } \\
\text { (ロードセル含む) }\end{array}$ & M12 & $19 \phi$ & 36 \\
\hline 風圧チューブ管 & $\begin{array}{l}\text { 外径 } \\
8 \mathrm{~mm} \phi\end{array}$ & $12 \phi$ & 14 \\
\hline ひずみダージ用配線 & $\begin{array}{c}3 \mathrm{~mm} \phi \\
3 \text { 本 }\end{array}$ & $8 \phi$ & 12 \\
\hline
\end{tabular}

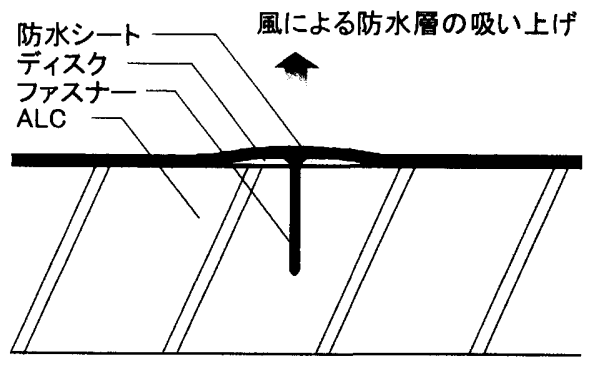

図2 ファスナーによる防水層の機械固定工法の例 （断熱材なし、ファスナー先付けエ法の例）

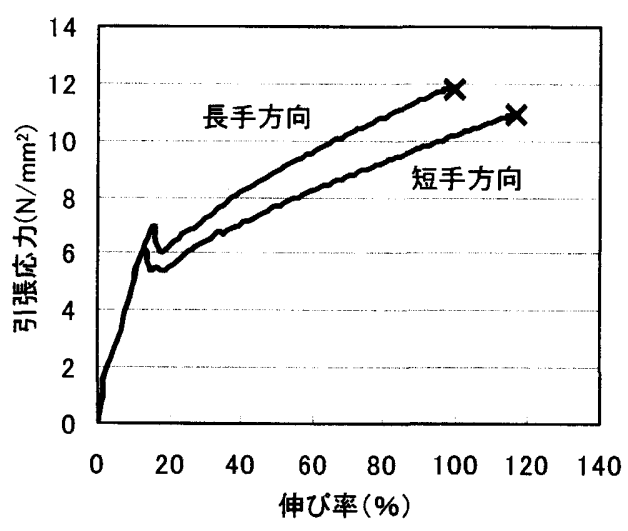

図3塩化ビニルシートの応カー歪曲線

(各々5本の平均値) 


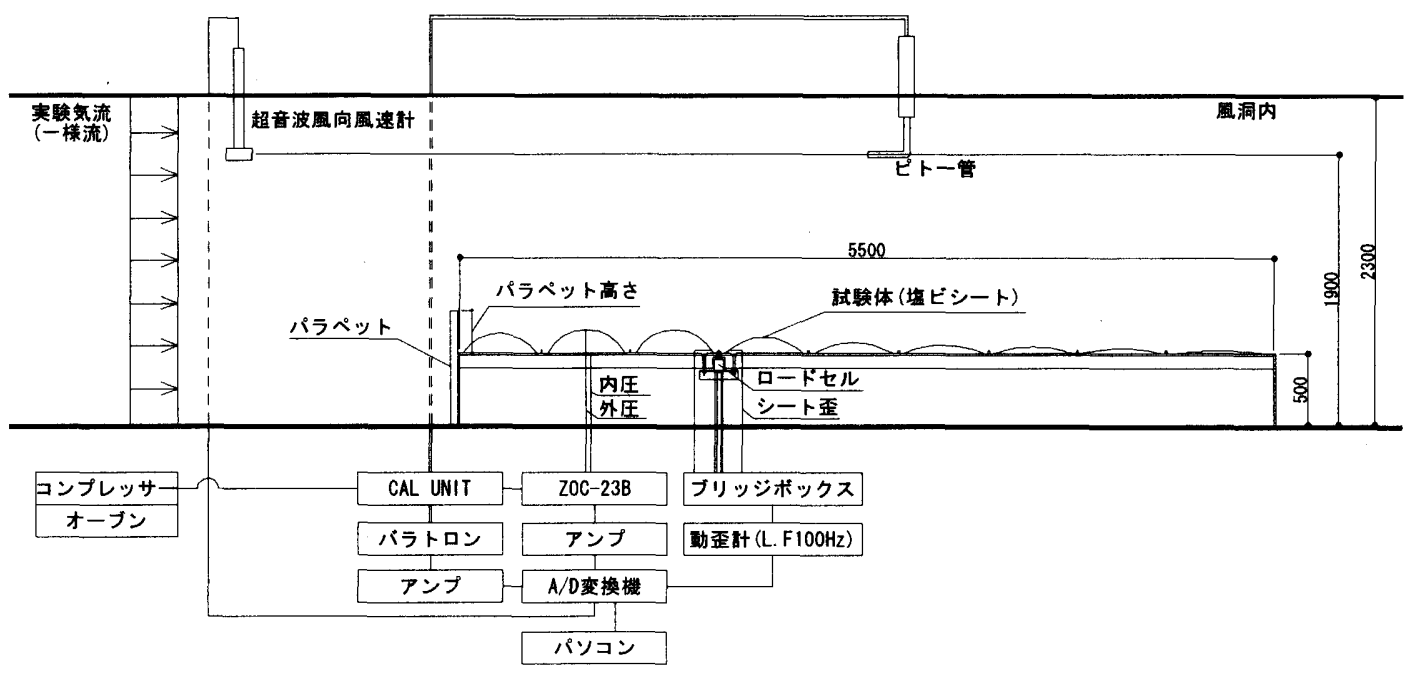

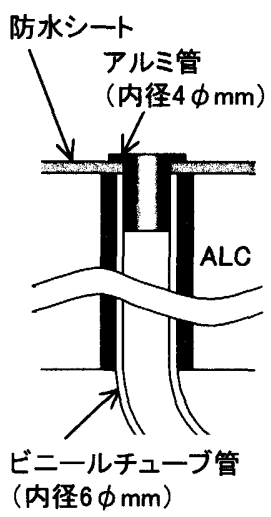

図5 風圧チューブ 設置断面図

図 4 風洞実験方法

\section{2 測定項目および測定条件}

(1) 風洞装置

試験に用いた風洞は、断面が高さ $2.3 \mathrm{~m}$ 、幅 $2.4 \mathrm{~m}$ の回流式境界層 風洞であり、試験体の風上には障害物を全く置かない状態で（一様 流）試験を実施した。今回の風洞試験の閉塞率（＝試験体の風上見

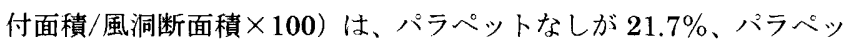
ト高さ $150 \mathrm{~mm}$ が $28.3 \%$ でる。

（2）防水層に作用する力

防水シートに作用寸る風圧力は、図 4 に示寸とおう、防水シート の表面と裏面（シートと下地との隙間）の圧力をビニールチューブ 管を用いてそれぞれ風圧計 (ZOC/23) に導き、その差圧を測定したも のである。

シート表面圧は、図 5 に示すシート表面に接着したアルミ管（内 径 $4 \mathrm{~mm} \phi$ ）にビニールチューブ管 (内径 $6 \mathrm{~mm} \phi$ : 長さ 6〜10m) をつな いで測定したものである。

なお、アルミ管およびビニールチューブ管はシートとともに自由 に動くようになっている。風圧力の測定点は、風上から風下に向か って 14 点、直線上に設けた。その測定位直在 6 に示寸。基本的 には荷重測定用ファスナー近傍での測定を行った。

風洞内風速の計測は、試験体中央の上部（屋根面から高さ $900 \mathrm{~mm}$ の位㯰）に設置したピトー管により測定したものである。
表 2 に示すように、風速を段階的に上げていき、風洞試験装置の 最大風速まで測定した。風洞内の試験状況を写真 2 に示す。

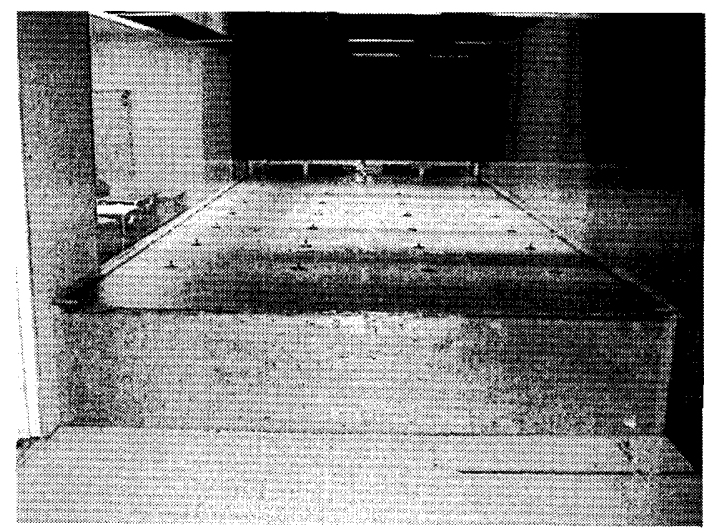

写真2 試験体状況（パラペット高さ $150 \mathrm{~mm} の$ 場

表 2 試験体に与えた風速

\begin{tabular}{|c|c|}
\hline パラペット & 風速 $(\mathrm{m} / \mathrm{s})$ \\
\hline なし & $18.7 \rightarrow 24.4 \rightarrow 30.0 \rightarrow 35.3$ \\
\hline あり(高さ $150 \mathrm{~mm})$ & $21.5 \rightarrow 28.6 \rightarrow 35.2$ \\
\hline
\end{tabular}

\begin{tabular}{|l|l|l|l|l|l|l|l|l|r|}
\hline 126 & 187 & 300 & 300 & 300 & 300 & 300 & 300 & 600 \\
\hline & 187 & & & & & & & & \\
\hline
\end{tabular}

(1)

(2)

(3)

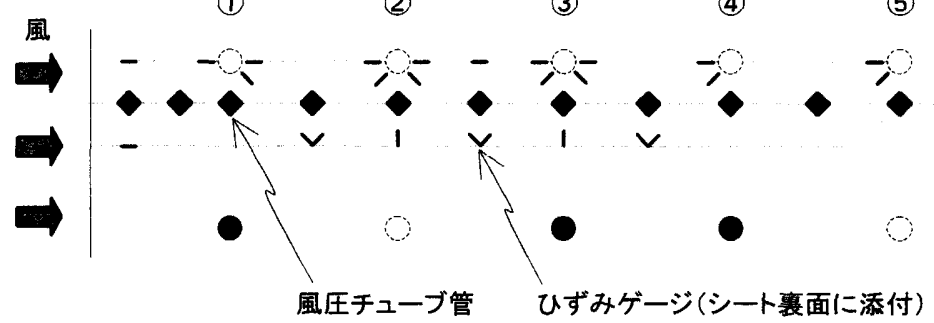

5400

図 6 各種測定位置詳細図（番号奻風上からのファスナー位置を示す。） 


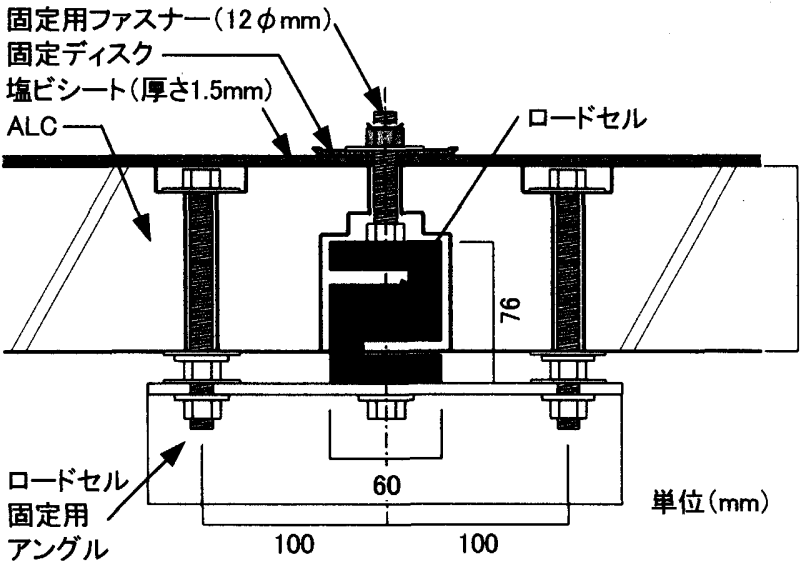

図 7 ファスナー部荷重測定用ロードセルの詳細図 (断面図)

\section{（3）防水層の変形}

防水層の変形は、塩化ビニルシート䯧面に貼り付けたひずみゲージ （宝温におうけるひずみ限界值：5\%）により測定した。

ひずみゲージの配置を同様に図 6 に示す、ファスナーの近傍およ びそれらの中間点に貼り付けた。

なお、実験前後の風洞内の温度は $15^{\circ} \mathrm{C}$ 前後であったが、実験中の 風洞内の温度測定は行っていない。

（4）ファスナーに作用する荷重

防水層を固定するファスナーに生じる力を、ロードセル（定格容 量 : $9.8 \mathrm{kN}$ 、非直線性 : $0.025 \%$ 以内）を用いて測定した。二れを図 7 に示すように、下地板に取り付けられた L 型アングルにロードセ ルを取り付け、下地に $15 \mathrm{~mm} の$ 孔開け、固定用ボルト $(12 \phi \mathrm{mm})$ を通して防水層を固定した。これら荷重状態測定用ファスナ一の設 置位置については、図6に示寸試験体側面ひ拘束ひ影響を受けない 中央部付近に設置した。

(5) 測定条件

各項目の測定条件を以下に示寸

$\begin{array}{ll}\text { ・サンプリング周波数 } & : 200 \mathrm{~Hz} \\ \cdot \text { ・゙ータ個数 } & : 12000 \text { 個 } \\ \text { ・測定時間 } & : 60 \text { 秒 }\end{array}$

ただし、測定風圧のチュービング補正を行うと、データ個数は

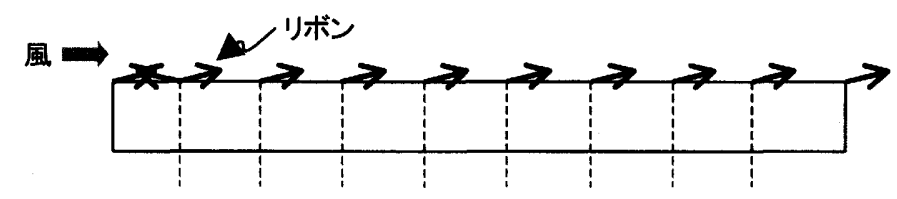

図10 試験体中心線上に設置したリボンの流れ状況 8 風 $\Rightarrow$ (パラペットなしの場合)

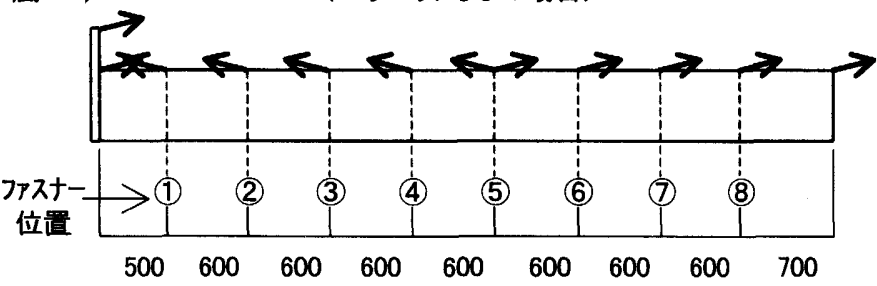

図11 試験体中心線上に設置したリボンの流れ状況 (パラペットありの場合)

8192 (測定時間にして 40.96 秒) となる。

\section{3. 試験結果及び考察}

今回の風洞実験にお污試験結果について、最大風速であった $35 \mathrm{~m} / \mathrm{s}$ の場合を例に述べる。

3.1 風による防水層の挙動の目視及びビデオによる钼測結果

防水層の挙動は、目視による観察とビデオ撮影により把握した。

風の作用により防水層は吸い上げられ、見かけ上ふくらんだよう な形態をとる。ただし防水層は $600 \mathrm{~mm}$ ピッチで下地に固定されて いるため、写真 3 に見られるように分節されたかくれが生じる。

また、風速が大きくなるに従いふくれ高さも大きくなっていく。 図 8、図 9 に風速 $35 \mathrm{~m} / \mathrm{s}$ における中央部のファスナ一線上部、及び 試験体の中心線（ファスナー線の中間）に沿って大まかなふくれ形 状を示寸。な㧍、この図ではふくれ高さを長さ方向の5倍に誇張し て示している。

(1) パラペットなしの場合

風上の防水層のふくれ高さが最も高く、風下にゆくに従って低く なる。またふくれは拡大・縮小を繰り返寸が、風上では早い周期で 小さくバタツキが生じるが、下流になるにゆっくり摇らぐ現象が見 られた。

また、風向きを観察するために、防水シート中央部にリボンを貼り

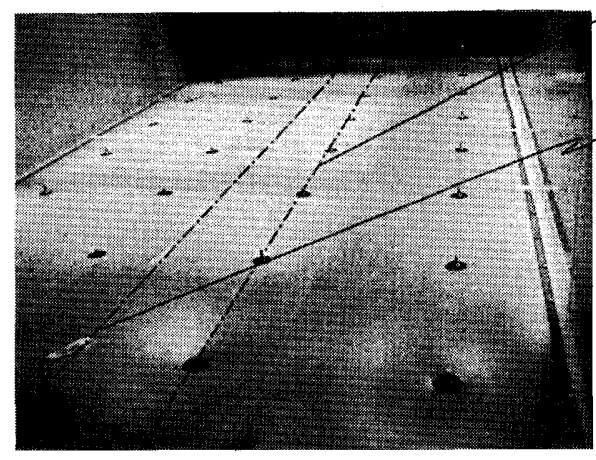

写真3 防水シ一トのふくれ状況

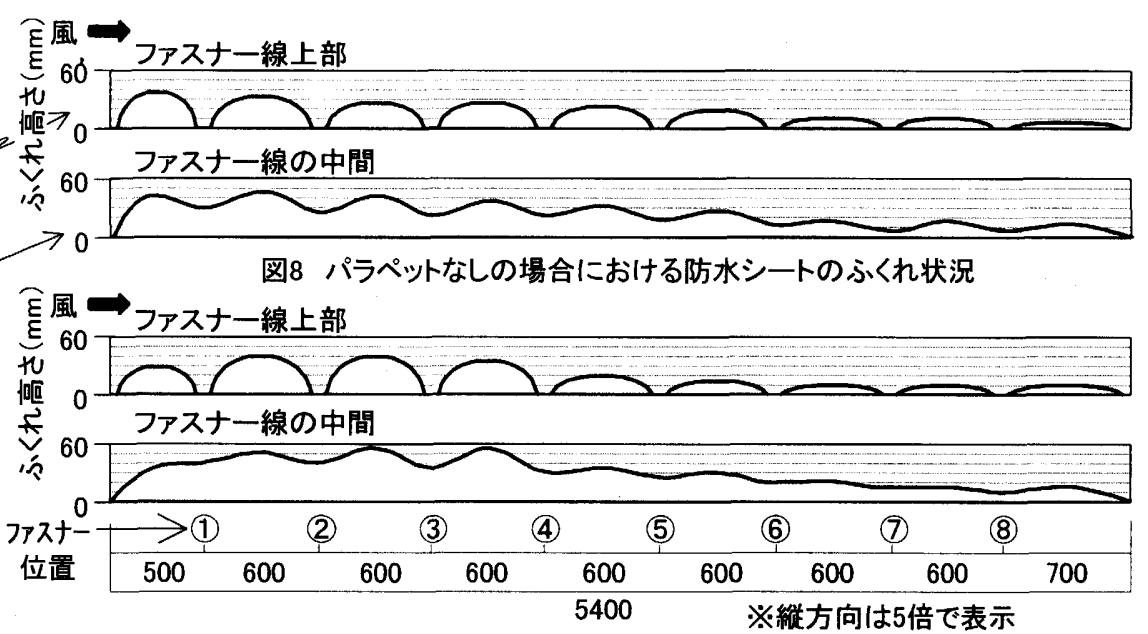

図9 パラペットあり(高さ150mm)の場合における防水シートのふくれ状況 


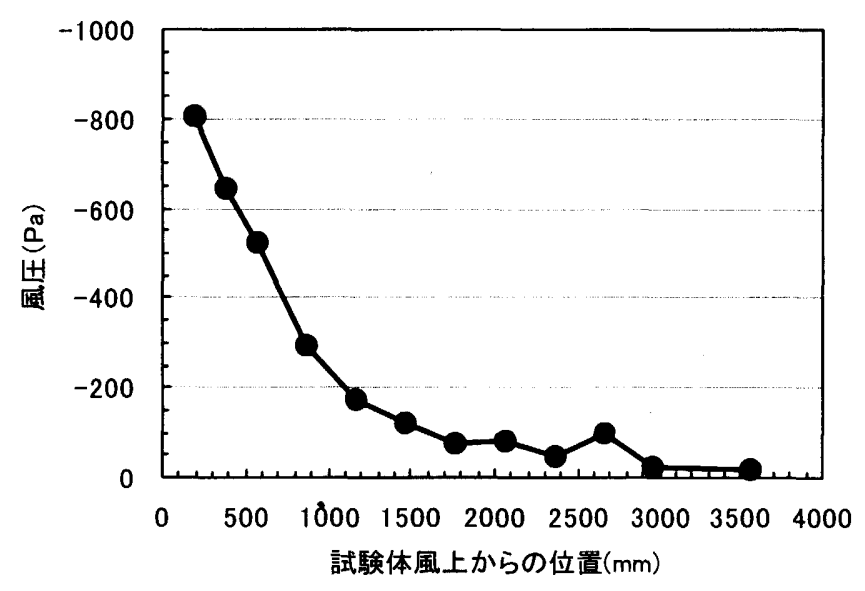

図 12 風圧力（パラペットなし）

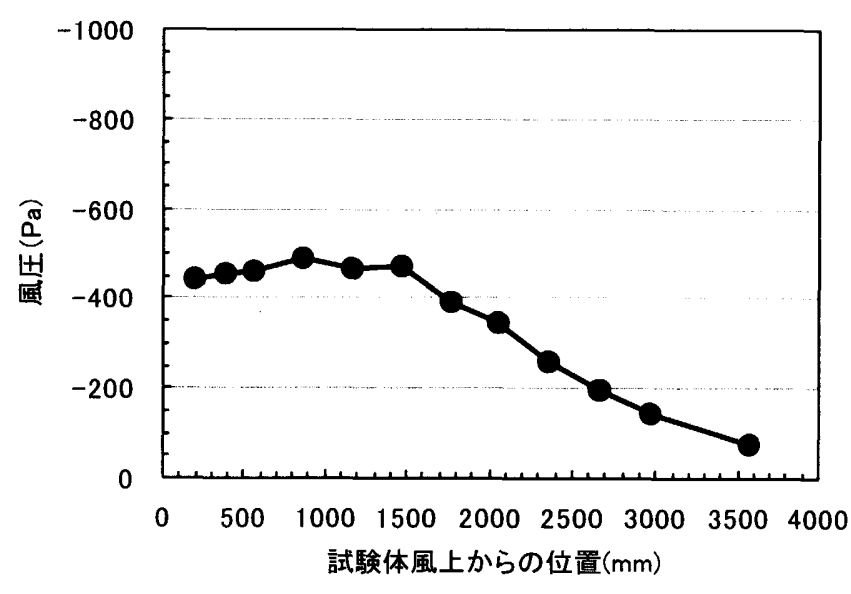

図 13 風圧カ(パラペットあり)

ボンが流れた。

\section{2 屋根面での風圧分布}

パラペットありなしによる風洞内気流 $35 \mathrm{~m} / \mathrm{s}$ 時の防水層に作用寸る 各計測点毎に測定した風圧力（シート表面と裹面との差圧）の平均 值を図 12、図 13 に示す。

(1) パラペットなしの場合

風上端部の計測点で風圧力-811Pa の大きな吸い上げ力が発生し、 端部から $1400 \mathrm{~mm}$ の計測点まで急勾配で小さくなり、1400 $\mathrm{mm}$ 以 降の計測点では-50Pa 近傍の小さな值を示すという風圧力分布が観 察された。

（2）パラペットありの場合

パラペットがあると風圧力分布は大きく変わる。バラペットの存 在の影響で風上端より $900 \mathrm{~mm}$ の位置で最大値となり、パラペット 際から風下側 $1400 \mathrm{~mm}$ の計測点まで汢約-500Pa とほぼ一定の吸い 上げ力を発生するが、そこから $3500 \mathrm{~mm}$ の計測点まで緩やかな勾配 で減少し、 $3500 \mathrm{~mm}$ の計測点では約-100Pa となった。

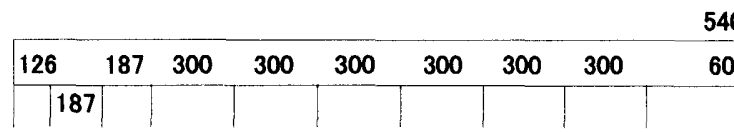

(1) (3) (4)
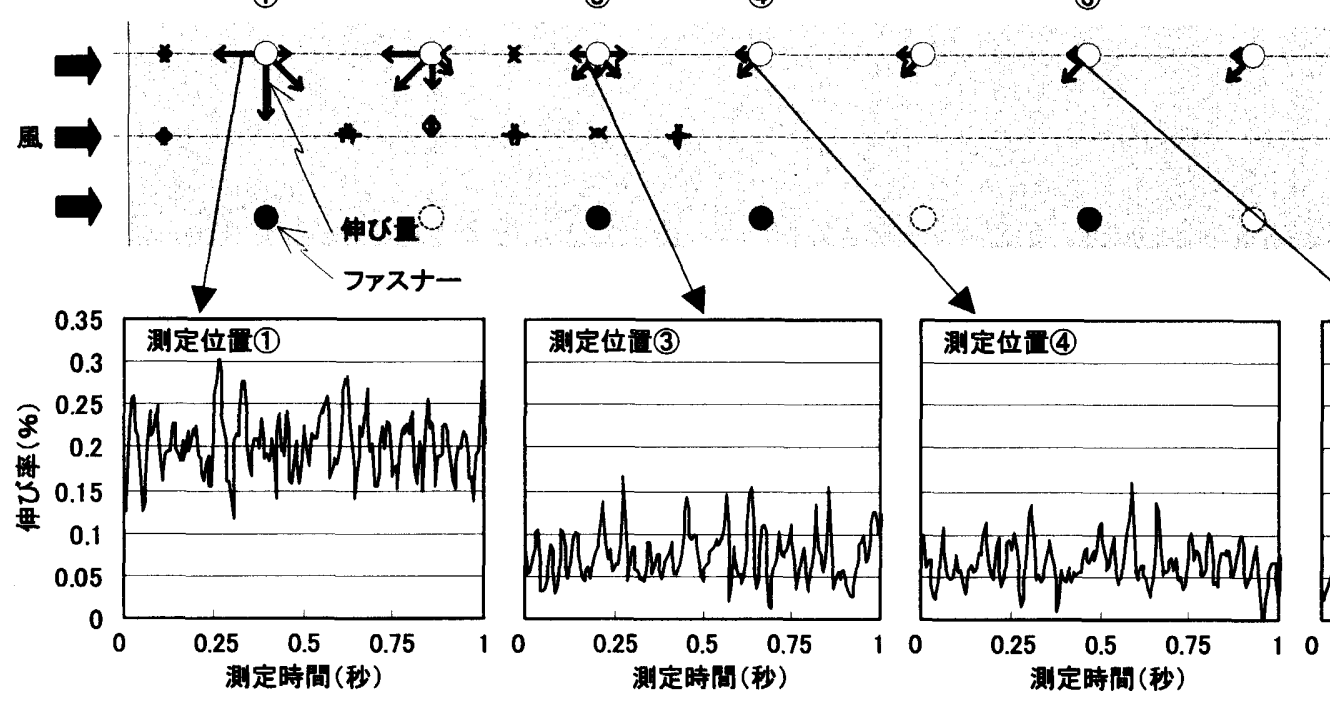

(6)

図 14 防水シートの平均伸びの分布と伸びの変化（パラペットなし） 


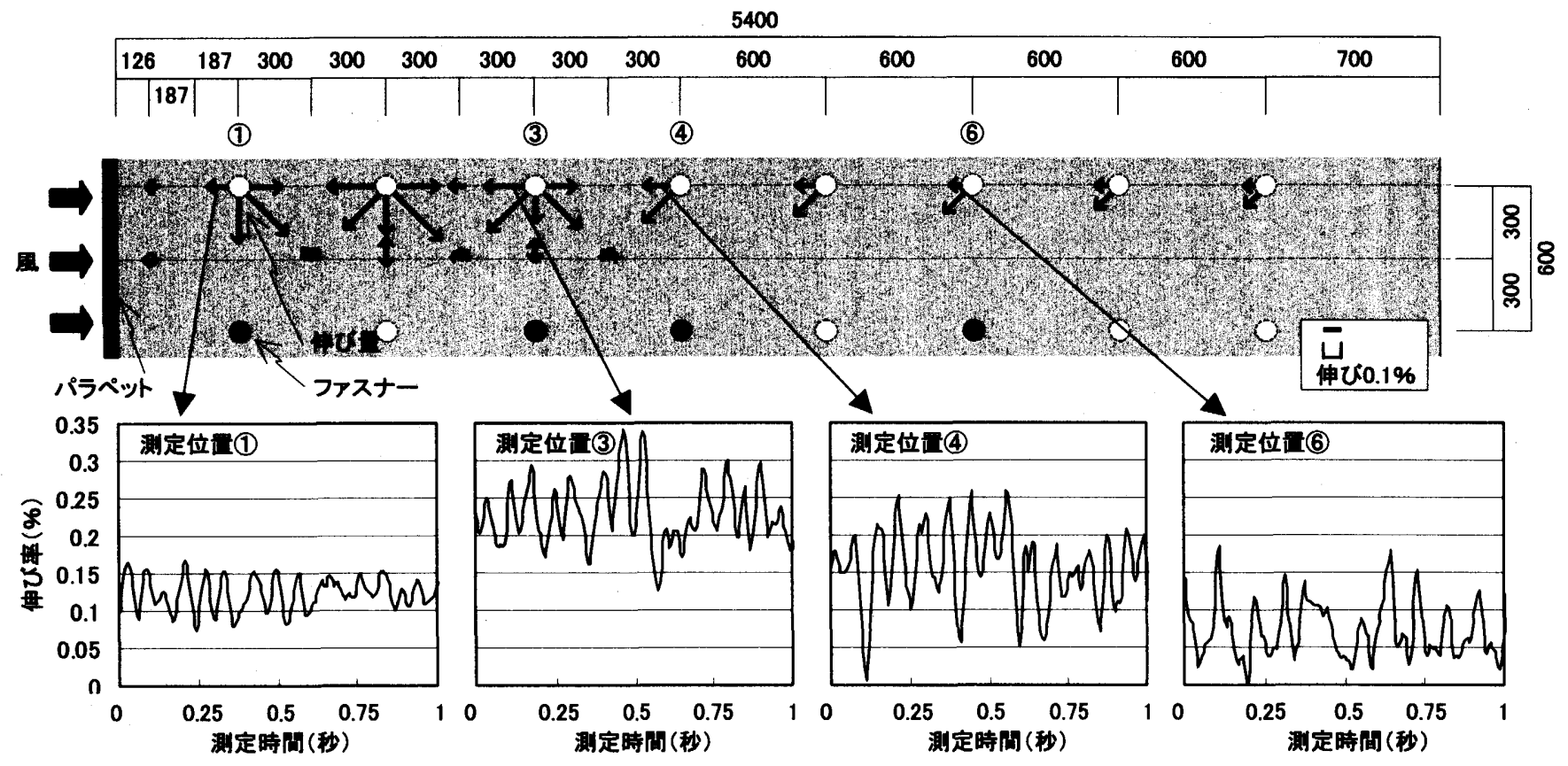

图 15 防水シートの平均伸びの分布と伸びの变化（パラペットあり、高さ $150 \mathrm{~mm}$ )

\section{3 防水層の変形}

パラペットありなしによる風速 $35 \mathrm{~m} / \mathrm{s}$ 時の防水層表面の伸びの 状態を、それぞれ図 14、図 15 に示す。伸びはひずみゲージの添付 した方向で測定されるため、その方向の伸びの測定時間 60 秒間で の平均値を知印の長さで示している。またファスナー傍に添付した ひずみゲージについては、風上から風下に向って位置による違いを 調べるため、図 14 、図 $15 に 4$ 点に㧍ける1秒間の举動の測定例を 示した。

\section{（1）パラペットなしの場合}

防水層はどの部分も引張伸びが観測されており、それは風上端部 で大きく、それが風下に向かうに従って小さくなる傾向が見られる。 伸びの大きくなる部分は、ふくれの頂部に向って風向きと直角方向 のファスナー側であり、平均最大伸びは $0.28 \%$ 、な打瞬間的には最 大 $0.47 \%$ の伸びが観測された。

伸びはかなり変動しており、風速 $35 \mathrm{~m} / \mathrm{s}$ の場合で周期は風上の測 定位置では $20 \mathrm{~Hz}$ 程度、風下では $10 \mathrm{~Hz}$ 以下に隇少する傾向が見ら

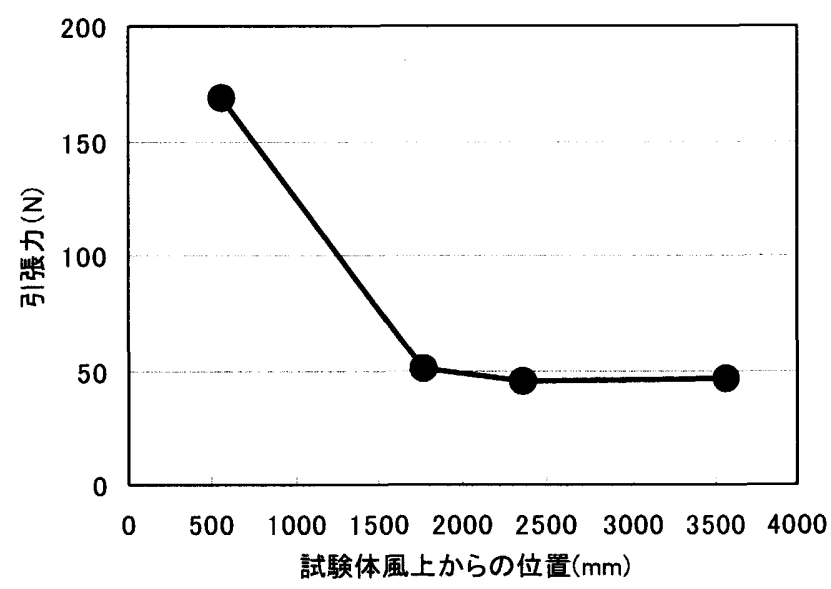

図 16 ファスナーに加わる引張カ（パラペットなしの場合）
れている。これはふくれのバタッキが風下になるほどゆっくりとな っているという観察結果を裏付けるものである。

(2)パラペットありの場合

防水層の大きく伸ばされる部分は、バラベットから $1 \mathrm{~m}$ 程度風下 の 2,3 列目のファスナー近傍であり、その平均最大伸びは $0.38 \%$ で あり、瞬間的には $0.55 \%$ の伸びが観測された。また防水層の大きく 伸ばされている領域は風上から $2 \mathrm{~m}$ 程度までにおよび、かなり広範 囲にわたりふくれの生じていることが示されている。

従来、建物の端部の外周屋根面老風圧力の高くなる範囲として、 防水層の耐風設計が行われてきたが、パラペットの存在により風圧 力の高くなる領域がさらに中央部まで拡大寸る傾向が認められるこ とから、今後はパラベットの高さによる影響と、より広範にわたる 領域での耐風性に対する研究や配慮が必要である。

バタッキは、パラベットなしに比べてゆっくりとしており、周波 数も測定位置(3)までは $20 \mathrm{~Hz}$ 弱であった。ただそれより風下のパラ ペットから 3500mm の位置ではさらに低下した。

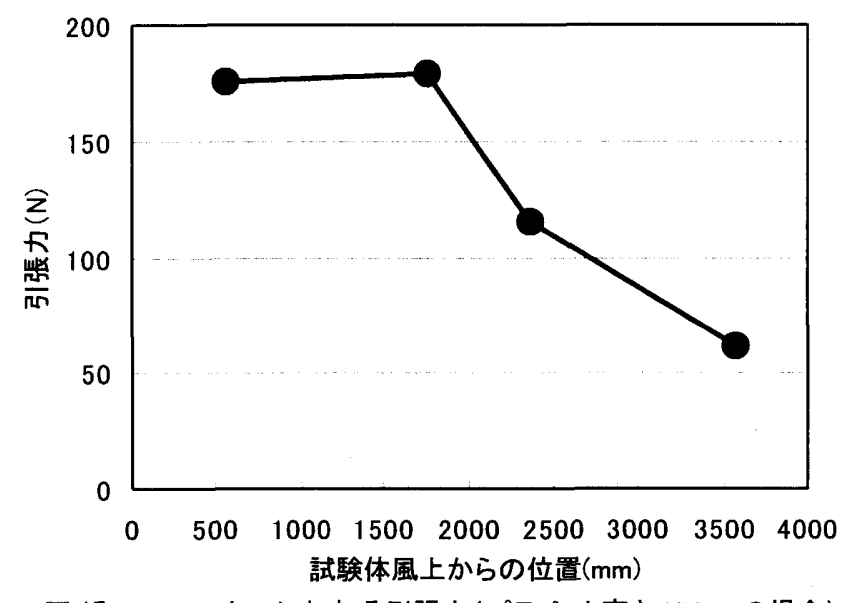

図 17 ファスナーに加わる引張カ(パラペット高さ $150 \mathrm{~mm}$ の場合) 


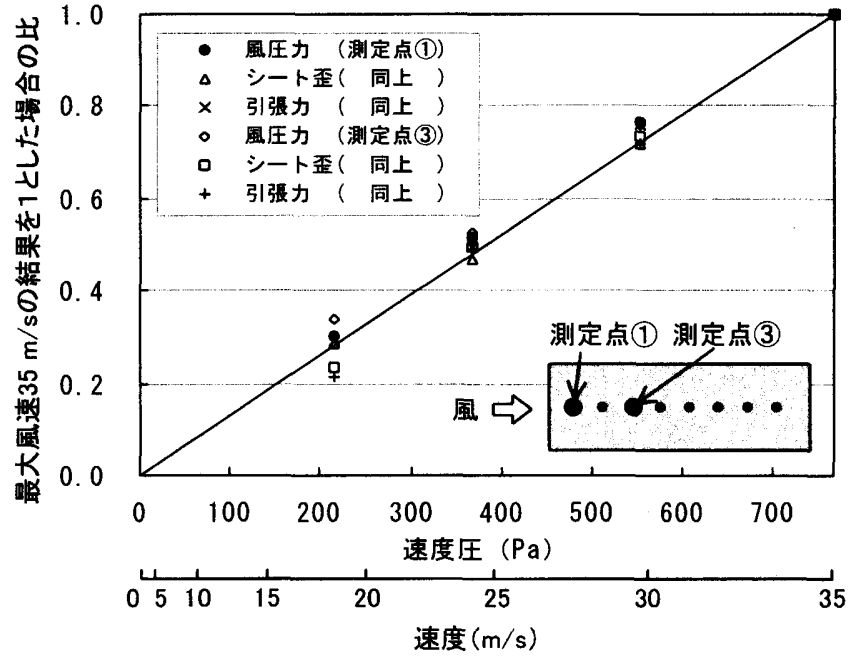

図18 速度圧と風圧力、シート伸び、ファスナ一作用カとの関係 (パラペットなし、測定点(1)および(3))

\section{4 ファスナーに作用するカ}

ファスナーに作用する力を、その下側に配置したロードセルによ り測定した。60 秒間測定した結果の平均值を図 16 、図 17 に示す。 (1)パラペットなしの場合

ファスナーには引張力が生じており、それは風上のファスナーで 大きく、風下に向って減少する。これは風上で大きな負圧の風圧力 が生じるためであり、風下では負圧が小さいため、ファスナーに生 じる引張力は低下する。

(2)パラペットありの場合

この場合は、引張力の大きくなるファスナーが、最も風上の位置 ではなく $1700 \mathrm{~mm}$ の位置に設置したものであった。これは負圧力が パラペットから $1 \mathrm{~m}$ 近傍で高くなっていることと符号する。図 12 の風圧力の分布から判断して、 $1100 \mathrm{~mm}$ 位置のファスナーの引張力 が最も高いものと推定されるが、ここではその位置での測定はなさ れていない。

\section{5 風速による影䈉}

これまで、今回計測した最大風速 $35 \mathrm{~m} / \mathrm{s}$ の場合の測定結果を中心 に述べてきたが、ここでは今回実施した他の風速での測定結果との 比較により、風速による影響について報告する。

パラペットありなしそれぞれにおいて、風速を変えてもリボンの 流れる向き、つまりシート面上を流れる風向きは変わらず、シート 面上を流れる風の方向が反転する位置は一定であった。

図18、図19 は、それぞれパラペットありなしの場合について、 風圧力の大きかった測定点(1)および(3)における各風速毎の測定結果 を、横軸に速度圧、縦軸に風圧力、シート伸び、ファスナーに作用 する力（引張力）を本実験での最大風速である $35 \mathrm{~m} / \mathrm{s}$ の結果を 1 と した場合の比で示した一例である。この図から、各測定点において、 速度圧と、風圧力、シート伸び、ファスナー作用力が比例関係にあ ることがわかる。

今回の風洞実験の結果、風速 $35 \mathrm{~m} / \mathrm{s}$ までの一様な風が流れる条件 において、速度圧と、風圧力、シートの引張り伸び、ファスナーに 作用する力はおのおの比例関倸にある。

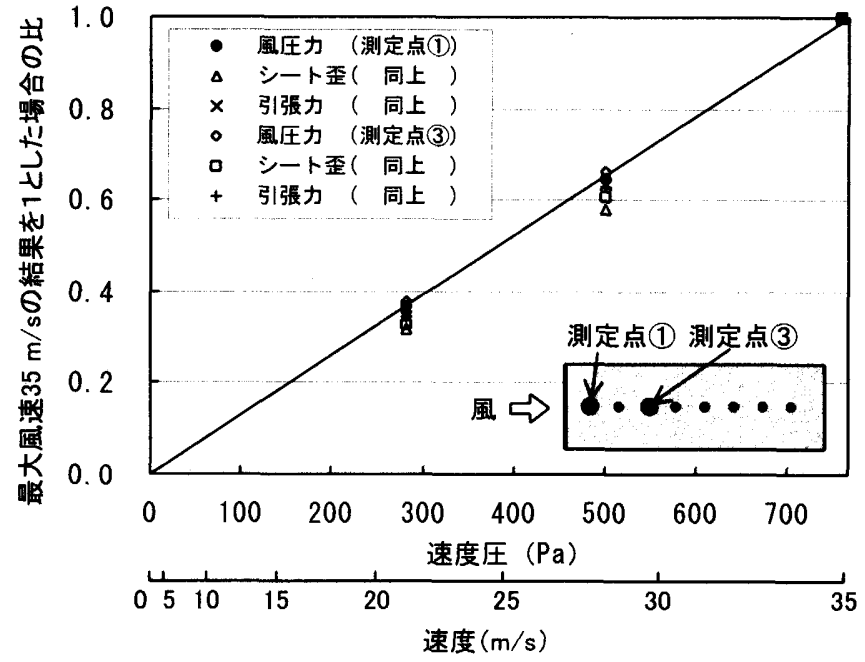

図19 速度圧と風圧カ、シート伸ひ、ファスナ一作用カとの関係 (パラペットあり:高さ150mm、測定点(1)および(3)

\section{4. 結 論}

強風時の防水層の举動に関して行われた、本報の結論をまとめる と以下のとおりである。

（1）強風のもとでは、防水層が負圧により吸い上げられふくれ状態 となる。防水層には引張伸びが生じ、それを支持するファスナ 一には引張力が生じる。

（2）パラペットのない場合、風圧力は風上端部で大きく、風下に向 い漸减する。そのためふくれの大きさ、防水層の伸び、ファス ナ一に生じる引張力も風上端部で大きく、風下で低下寸る。

（3）パラペットの存在の影響は大きく、パラペットがある場合は、 その際より風下に離れた領域で風圧力が高くなり、それに伴い ふくれの大きさ、防水層の伸び、ファスナーの引張力も風上端 部より屋根中央部に寄った風下位置で大きくなる。

従来、屋根外周部を風圧力が高くなる範囲として、防水層は 耐風設計されていたが、バラペットの存在により影響範囲がよ り広範囲に及ぶ。

（4）防水層に生じる伸びはファスナー近傍で大きいが、ふくれのサ イズと関連しており、大きなふくれでは大きく伸張している。 またそのバタッキの周期は数 $\mathrm{Hz}$ から $20 \mathrm{~Hz}$ 程度であり、風上 に比べ風下が遅くなる。防水層のバタッキについては、かなり の変動が見られる。

（5）バラペットある場合もない場合も、それぞれ防水シート面上を 流れる風の方向は一定で、風速によってシート面上の風の向き は変わらない。また、風速 $35 \mathrm{~m} / \mathrm{s}$ までの一様な風が流れる条件 において、速度圧と、風圧力、シート引張り伸び、ファスナー 一作用する力はおのおの比例関係にある。

\section{謝 辞}

本研究は（社）日本建築学会・防水工事運営委員会・防水層 ALC 機 械固定工法WG の研究活動の一部であり、委員各位には試験体作成、実 験等で多大なご協力をいただきました。また合成高分子ルーフィング工 業会、アスファルト防水工業会、トーチ工法ルーフィング工業会、日本 ヒルティ（株）、JPF ワークス（株）、サンコーテクノ（株）、峰岸（株） 
からは研究費の一部をご援助をいただきました。心より感謝いたします。

\section{参考文献}

1) Gerhardt, H. J., Gerbatsch, R. W.: Wind resistance of mechanically attached, single-ply systems fastener load, safety considerations and optimal fastener patterns, Third international symposium on roofing technology, Rosemont, pp. 276-283, 1991

2) E. M. Paulsen: Dynamic Loading Test for Mechanically Attached Roofing Systems, Proceedings of the $8^{\text {th }}$ congress of the International Impermeability Association, pp.: 431-443, May 1992

3) Malpezzi, J. A., Gillenwater, R. J.: Static vs. dynamic: a wind uplift testing study, $10^{\text {th }}$ conference on roofing technology, Maryland, pp. 123-129, 1993

4) F. Granne, F. Bjork: Wind Load Resistance Test of Heat-welded Joints Between
Roofing Felt and Sheet Metal Flashings, Proceedings of the 11 the International Waterproofing Association Congress, Florence, pp.: 13-22, 2000

5) Baskaran, A., Chen, Y.: Wind Load Cycle Development for Evaluating Mechanically attached Single-ply Roofs, Journal of Wind Engineering and Industrial Aerodynamics, pp.: 83-96, 1998

6) Baskaran, A., Chen, Y., Lei, W.: Wind Load Resistance of Modified Bituminous Roofing Systems, Construction and Building Materials, pp.: $471-480,1998$

7). Baskaran, A., Chen, Y., Vilaipornasawai, U.: A New Dynamic Wind Load Cycle to Evaluate Mechanically Attached Flexible Membrane Roofs, Journal of Testing and Evaluation, pp.249-265, 1999

8）日本建築学会：建築物荷重指針・同解额、2004 